
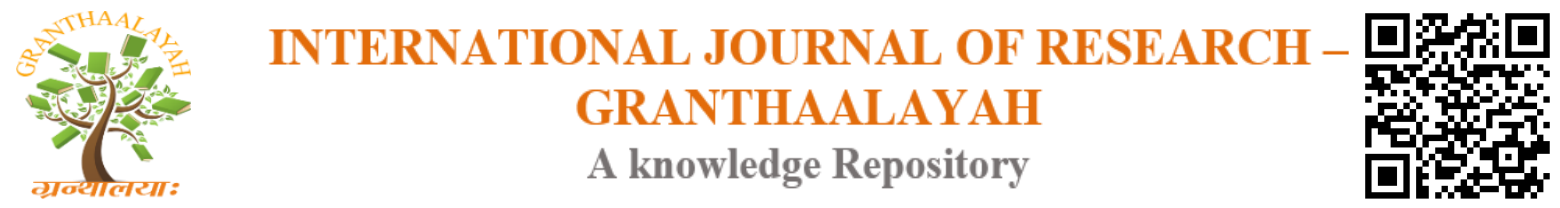

Management

\title{
ANALYSIS OF BREAK-EVEN POINT IN CV.BATA CIKARANG INDONESIA
}

\author{
Agus Jamaludin *1 \\ ${ }^{* 1}$ Unindra, Indonesia
}

\begin{abstract}
This study was obtained from the balance sheet and income statement of CV Bata Cikarang Indonesia in 2018, then the title is: Break Event Point Analysis on CV Bata Cikarang Indonesia. The goal is to find out the performance of CV Bata Cikarang seen from the company's Break Event Point. The research method is Field Research by visiting research objects and conducting interviews, and Library Research by exposing existing data in the form of Balance Sheet and Profit and Loss reports, and sales of data in the form of quantitative data and in the form of descriptive. Break Event Point analysis is performed to determine the company's financial performance, can also be used as a reference in making decisions that affect the company's future. As for the results in 2017 the BEP unit is 1,055,194 and the rupiah BEP is IDR 422,077,922 and 2018 the BEP unit $=1,027,397.26$ and the IDR BEP is IDR 462,392,108.
\end{abstract}

Keywords: Red Brick; Break Event Point.

Cite This Article: Agus Jamaludin. (2019). "ANALYSIS OF BREAK-EVEN POINT IN CV.BATA CIKARANG INDONESIA.” International Journal of Research - Granthaalayah, 7(9), 259-267. https://doi.org/10.29121/granthaalayah.v7.i9.2019.609.

\section{Introduction}

Development in the Jabobetabek area is very rapid, in Jakarta the construction of apartments, buildings, housing and others, is also accompanied by the cities supporting the capital such as Bogor, Bekasi, Depok and Tangerang. material including red brick. Red brick is a material for building construction, housing, apartments and others.

Every business venture is established with the aim of making a profit. Profit in a business is the main goal and dizziness in the company. Advantage is one measure of the success of company management in operating a company. Considering that efforts to make a profit are not easy, all activities must be planned well in advance. The management of a company must mobilize and direct all units in the company to achieve one goal, which is to make a profit. Thus all participants and business units take responsibility i achieving these business goals. There are several external and internal factors that can affect the level of profit earned by a company, namely: 1 The amount of costs incurred to produce a product / service that is reflected by the cost of goods sold (HPP) or 
the cost of goods sold (cost of goods sold), 2 Number of goods / services produced and sold,3.The selling price of the goods concerned. Efforts to achieve the planned profits of the company are influenced by the activities of these elements, so that the company's management must try to control these three things.

The thing that needs to be pursued is so that all goods produced can be sold. In order to determine income, it is assumed that the goods produced are sold out entirely. On the factors that affect the level of profit, the management's efforts can make the emphasis on costs to the level of the minimum cost. On the other hand the sales volume of goods / services can be increased to the maximum level, so that the goods produced are sold out.

The determination of the selling price is determined by achieving an adequate level of profit per unit, so that the selling price can be reached by the public-consumer. The effort of the company's management in an effort to find profits must be based on how many items must be produced and then sold. In the production planning stage, company management must determine in advance the minimum level of production so that the company does not lose. In other words, the initial stage of production planning must be based on efforts to not lose or break even. The purpose of breakeven is the company's total revenue (total revenue) is the same as the total costs incurred (TR $=\mathrm{TC}$ ).

\section{Literature Review}

\section{Definition of Break Even Point}

Break even point is a condition where the company does not make a profit and does not suffer losses. According to Noor (in Razak et al., 2015: 2) break even point analysis is the main return point or level of production where the company does not experience losses but also does not make a profit. Break even point analysis is useful to find out the break even point of the company where revenue equals the costs incurred by the company. According to Martono and Harjito (in Razak et al, 2015: 2) break even point analysis or break-even analysis is an analytical technique to study the relationship between costs, profits, and sales volume.

Based on some of the opinions above, it can be concluded that the break even point analysis is a tool used to determine the break even point of the company where the company does not experience losses and does not get profits. Break even point analysis can be seen the minimum revenue that must be achieved by the company in order to obtain the targeted profit for the following year.

\section{Requirements Required in Break Even Point Analysis}

number of specific.requirements are needed so that a break-even point analysis or break-even point from a company can be carried out. The requirements needed to determine the break-even point are as follows (Badirika, 2012: 40):

- The principle of cost variability can be applied precisely.

- Costs that are sacrificed must be separated into two groups of costs, namely fixed costs and variable costs. Doubtful (semi-variable) costs must be confirmed by the group because in the break-even analysis there are only two cost groups, namely fixed costs and variable costs. 
- Costs classified as fixed costs must be constant throughout the range of work periods, which means they do not change even if the volume of activity changes.

- Costs that are classified as variable costs will change in proportion to changes in the volume of activities, which means the higher the volume of activities, the higher the variable costs will be.

- The selling price per unit of goods / services will not go up or down regardless of the number of units of goods / services sold. The price per unit will not decrease even though the sales volume increases, and conversely the sales volume will not affect the selling price or the market price. This requirement applies to perfectly competitive market goods where the company individually cannot influence market prices.

- The general price level will not change during the specified range analyzed.

- The company concerned only produces and sells one type of goods / service. For companies that produce and sell more than one type of product, the product / service must be considered only one type of product with a constant ratio.

- Labor productivity at the company concerned remains unchanged.

- The company concerned must have a synchronization between the production volume with the sales volume, meaning that the goods / services produced must all be sold in ther elevant period.

These conditions must be met so that we can determine the level or volume of sales that will produce a break even point, meaning that it does not provide profit and not suffer loss.

\section{Break Even Point Analysis Method}

According to Madagascar (2012: 3) to determine the condition of Break Even Point a company can be used sever always, namely:

\section{Trial and Error Approach}

BEP calculation using the Trial and Error approach (trial and error) is to calculate the operating profit of a certain production / sales volume and is repeated to produce a production / sales volume that produces a profit $=0$ (total revenue $=$ total cost). If the calculation generates profit then recalculate by taking a lower sales volume or production otherwise if the calculation results suffer losses then recalculate by taking a larger sales / production volume. And so on until sales / production volumes are achieved where sales results equal total costs.

\section{Graphical Approach}

The graphical approach is done by describing the elements of costs and income into a graph. In the figure you will see lines of fixed costs, total costs that describe total fixed and variable costs, and sales revenue lines. The size of the production / sales volume in the unit is represented on the horizontal axis ( $\mathrm{X}$ axis) and the magnitude of the costs and sales income is represented on the vartical axis (Y axis). To draw a fixed cost line in a break even point graph, you can do it with two searches, namely by drawing a fixed cost line horizontally parallel to the $\mathrm{X}$ axis, or by drawing a fixed cost line parallel to the variable cost line. Determination of break-even points on the graph, namely at the point where there is a cross between the sales income line and the total cost line. If the point we draw a vertical straight line down until the X-axis will show the magnitude of the break even point in the unit. And if the point is stretched horizontally to the Y axis, the break even point will be seen in rupiah. 


\section{Mathematical Approach}

BEP calculation with a mathematical approach using algebraic formulas can be done in two ways, namely on the basis of units and on the basis of the value of sales in rupiah.

Calculation of break even points on a unit basis can be done using the formula: $\mathrm{BEP}($ Unit $)=($ fixed costs $) /($ contingent profit in units $)$

Break even point calculation based on the value of sales in rupiah can be done using the formula: $\mathrm{BEP}(\mathrm{Rp})=($ fixed costs $) /(1-($ variable costs $) /$ sales $)=($ fixed costs $) /($ profit contribution $)$.

\section{Use of Break Even Point Analysis.}

Break Even Point analysis has several uses. According to Sutrisno (In Isaskar, 2012; 2) The usefulness of BEP analysis namely;

1) Planning production and sales according to the desired target;

2) Planning the normal selling price of the coal produced to achieve the targeted profit by projecting the sales target;

3) Determination of the factory closing point (Shut Down Point), i.e. when sales are unable to cover variable costs and fixed costs in cash. Based on the explanation, it can be understood that the usefulness of BEP analysis is planning and determining the plant's closing point. Where the intended planning is planning production, sales, selling prices, and production methods.

According to Halim (in Badirika, 2012: decisions, namely:

1) The minimum number of sales that must be maintained so that the company does not lose,

2) The number of sellers that must be achieved to obtain a certain profit

3) To what extent can sales turnover so that the company does not lose,

4) To what extent the effect of changes in selling prices, prices, and sales volumes on profits obtained. Based on the expert opinion above, it can be understood that the BEP analysis can be used to find out the minimum number of sales, the number of sales that must be achieved to obtain the expected profit, the limit of sales decline, as well as the effect of changes in selling prices, costs, and sales volume on the profit received.

5) Limitations of Break Even Point Analysis.

Besides having benefits, break even point analysis also has disadvantages. The lack of break-even point analysis mainly comes from the assumptions used (Muslich, 2000; 78). According to Isaskar (2012: 2) the basic assumptions that must be met in using the break even point are:

1) Costs within the company are classified into two types of costs, namely variable costs and fixed costs. If there are semi-variable costs must be allocated to the se two types of costs

2) The amount of variable costs in total changes proportionally to the volume of production / sales. This means that the variable cost per unit is the same.

3) The amount of fixed costs in total does not change even though there is a change in production / sales volume. This means that fixed costs per unit change because of changes in activity volum

4) The selling price per unit does not change during the analysisperiod.5. The company only produces one type of product. If more than one product is produced, sales revenue growth between each product must be constant. 
Types of Costs Based on Break Even Point.Costs incurred by the company can be distinguished as follows:

1) Variable Cost (Variable cost). Variable cost is a type of cost that always changes according to changes in sales volume, where the change is reflected in total variable costs. In this sense variable costs can be calculated based on a certain percentage of sales, or variable cost per unit multiplied by sales in units.

2) Fixed Cost.Fixed cost is a type of cost that is always fixed and is not affected by sales volume but is linked to time (function of time) so that this type of cost will be constant for a certain period. Example rent, depreciation, interest. Whether or not the company manufactures these costs is still incurred.

\section{Semi Variable Cost.}

Semi variable cost is a type of cost that is partly variable and partly fixed, which is sometimes called a semi fixed cost. Costs classified as this type for example: 1.Sales expense or commission for salesmen where the commission is shared Accounting Development laboratory This salesman remains for a certain range or volume, and rises at a higher level.

\section{Break Even Point Level}

To be able to determine the level of Break Even, the costs incurred must be separated into fixed costs and variable costs. The greater the yield of production, the tetan cost of unity will be increasingly small, conversely the lower the production results the fixed costs of unity will be even greater. Separation of variable costs and fixed costs in practice is usually not an easy problem. Types of semi-variable or semi-fixed costs using certain methods.

Calculations to determine the area of operation at the level of Break Even can be done using a certain formula, but [I to illustrate the volume level with the profit, then a Break even chart or chart is needed. Mathematically the level of Break Eve can be determined by sharing formulas. Thus the level of Break Even can be determined by two approaches, namely a mathematical approach and a graphical approach.

Here are some formula models that can be used in Break Even Point (BEP) analysis, namely as follows:

\section{Mathematical Approach}

The first BEP formula is to calculate the Break Even Point that must be known is the number of fixed cost boxes, variable costs per unit or total variables, total sales results or selling price per unit. The formula that can be used is as follows:

Break Even Point in "Unit"

$$
\mathrm{BEP}=\frac{\mathrm{FC}}{\mathrm{P}-\mathrm{VC}}
$$

Formula description: BEP: Break Even.Point FC: Fixed Cost VC: Variable Cost P:Price per unit S:SalesVolume

.b. Break even point in "rupiah". 


$$
\mathrm{BEP}=\frac{\mathrm{FC}}{1-\frac{\mathrm{VC}}{\mathrm{S}}}
$$

\section{Graphic Approach}

Break Even Point analysis with a graphical approach is illustrated by a graph called the break even point. Break Even Point calculation can be done by determining the meeting point or the cut point between the sales revenue line and the cost. The meeting point is the breakeven point. Munawir (2004) explains the Break Even Point graphical approach:" In determining the Break Even Point point can also be done with a chart or chart, with the Break Even Point graph, management will be able to know the relationship between costs, sales (sales volume), and profits". To determine the breakeven point, a graph must be made with a flat axis (horizontal) that shows sales volume, while the vertical axis shows vertical costs and income. By looking at the Break Even Point chart, it can be seen that the Break Even Point point occurs at a point where there is an intersection between the sales line and the line of total costs (variable costs + fixed costs), so that if the level of sales occurs at the Break Even Point, the company does not suffer profit nor does it obtain profit, if the point of the company's sales level is to the left of the Break Even point the company is said to suffer losses, and if the company's sales level is at the point to the right of the Break Even Point, means the company gets a profit.

For more details, it can be seen in the picture as follows:

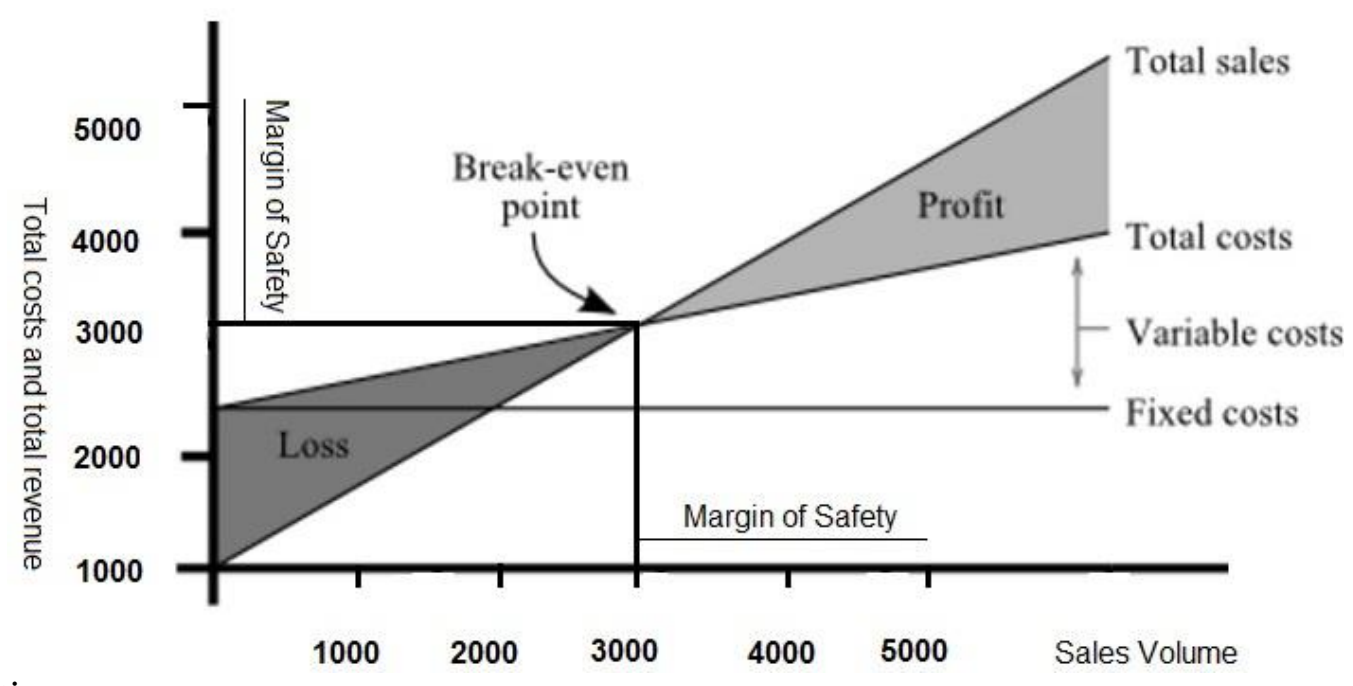

Information:

1) Flat growth $(\mathrm{X})$ shows the sales volume that can be expressed in units of quantity or rupiah sales revenue.

2) The vertical axis (Y) shows sales revenue and costs in rupiah

3) Making the sales line is done as follows: o On sales volume equals zero and income equals zero. o A straight line is then drawn to connect the points $\mathrm{x}=0$ and $\mathrm{y}=0$.

4) Line construction is still carried out because the fixed costs in any sales volume does not change in certain capacities.

5) The break even point is located at the point of intersection of the sales revenue line with the cost line. 
6) The area on the left of the breakeven point, namely the area between the total cost line and the sales revenue line is the area of loss, because sales revenue is lower than the total cost, while the area to the right of the breakeven, the area between sales revenue with the total cost line is the area profit, because sales revenue is higher than total costs.

\section{Assumption Break Even Point Analysis \\ Supposition}

According to Munawir (2007: 204) states that the assumptions in the Break Even Point analysis are used the following basic assumptions:

- Costs must be separated or classified into two, fixed costs and variable cost costs can be applied appropriately.

- That total fixed costs will always be constant to the full capacity level.

- That variable costs will change proportionally with changes in sales volume and synchronization between production and sales.

- The selling price per unit of goods will not change regardless of the number of units sold or there is no general change in price.

- That only one item is produced or sold or if more than one type, the sales mix will remain constant.

\section{Research Methodology}

This research was conducted from the results of PT. Abadi Motor's financial statements in the form of sales reports for 2017 via the internet. This research method uses the Library Reserch method by exposing existing data in the form of sales reports, quantitative and descriptive research data, research instruments in the form of library research by searching from the internet and books, and scientific works related to the title of this research,

\section{Research Results}

The study was conducted at CV Bata Cikarang Indonesia CV Bata Cikarang Indonesia is one company that focuses its business in the field of red brick sales. In carrying out its business activities, the company demands that sales performance can be improved in order to achieve maximum profit.

Table 1: Sales data of CV Bata Cikarang Indonesia

\begin{tabular}{|l|l|l|l|}
\hline Year & Price (Rp) & Sales & Sales Value (Rp) \\
\hline 2017 & 400 & 1.825 .000 & 730.000 .000 \\
\hline 2018 & 450 & 2.190 .000 & 985.500 .000 \\
\hline
\end{tabular}

The increase in red brick sales was due to the jabodetabek area being actively building, especially the cities supporting the capital, namely: Bekasi, Depok, Bogor, and Tangerang, which had a lot of housing construction, also in the capital many apartments, office buildings, hotels and housing developments. 


\section{Company Sales and Costs}

In 2018 there was an increase in the price of red brick by Rp50, - but the interest of the community to have a house remains high, there was an increase in sales of 365,000 there was an increase of $20 \%$ from 2018, so there was an increase in sales value of Rp. $255,500,000$ or an increase of $35 \%$ from in 2017.

The variable costs of the company for the period of 2017 are Rp 168,000,000. In 2018 variable costs amounted to Rp.186,000,000. This amount has increased from 2017 to 2018 amounting to Rp.18,000,000. Fixed costs in 2017 amounted to Rp325,000,000, in 2018 amounting to


the increase in engine maintenance costs which also includes the cost of engine repair caused by a machine that is damaged. Based on company revenue and cost information, it can be seen the amount of profit. Profit obtained from 2017 was IDR 237,000,000, and in 2018 the profit was IDR $424,500,000$. This was due to increased production, and increased sales.

Table 2: Sales and Production Costs of Bata Merah CV Bata Cikarang Indonesia

\begin{tabular}{|l|l|c|}
\hline Red brick products & 2017 (Rp) & 2018 (Rp) \\
\hline Sales & 730.000 .000 & 985.500 .000 \\
\hline Variabel cost & 168.000 .000 & 186.000 .000 \\
\hline Fix Cost & 325.000 .000 & 375.000 .000 \\
\hline Profit & 237.000 .000 & 424.500 .000 \\
\hline Contribution Margin & $\mathbf{5 6 2 . 0 0 0 . 0 0 0}$ & $\mathbf{7 9 9 . 5 0 0 . 0 0 0}$ \\
\hline
\end{tabular}

\section{Analysis Break Even Point}

Break Even Point Analysis

Company BEP 2017 period, namely:

FC 325,000,000

BEP seeds $=$----------- = -------------- $=1,055,194.8$ seeds

$\mathrm{P}$ - VC / unit $400-92$

FC 325,000,000

IDR BEP = ---- = ------- 168,000,000 / 730,000,000

Company BEP 2018 period, namely:

FC 375,000,000

BEP seeds = ------- = --------------- $=1,027,397.26$ seeds

FC $375,000,000$

IDR BEP =

$$
1 \text { - VC / S } 1 \text { - 186,000,000 / 985,500,000 }
$$

With this BEP analysis in mind it will be useful in providing information for company leaders in taking and determining future production and marketing policies. 


\section{Conclusions and Suggestions.}

\section{Conclusion}

1) In 2017 CV Bata Cikarang Indonesia got a profit of $\operatorname{Rp} 237,000,000$ and in 2018 the profit

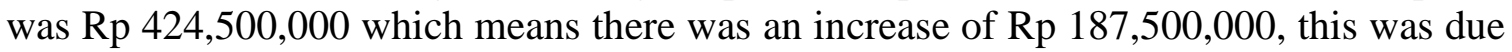
to an increase in sales.

2) In $2017 \mathrm{CV}$ Bata Cikarang Indonesia BEP units $=1,055,194.8$ seeds, and IDR BEP 422,077,922, while in 2018 BEP units $=1,027,397.26$ seeds and IDR BEP Rp 462,392,108, -, meaning that there is a decrease in the BEP of the number of red brick products by 27798 units while the rupiah BEP has an increase of Rp 40,314,186, - this is because there is an increase in the price of red brick Rp. 50, - per unit.

\section{Suggestion}

1) The leadership of the company should pay attention to BEP both units and rupiah in order to become a benchmark in producing and marketing red bricks

2) Companies should increase sales so that sales profits will increase.

\section{References}

1) Muhajjir Afif, Wahyu. 2014. Break Even Point Determination Analysis on Spirulina Products at PT Neoalgae Indonesia Makmur. Journal of the Faculty of Economics; Economic echo.

2) Nuril Dwi Rahayu. 2017. Application of Break Even Point (BEP) as a Profit Planning Tool. Thesis in Administrative Sciences; University of Jember.

\footnotetext{
*Corresponding author.

E-mail address: Agus_jamaludin63@yahoo.co.id
} 